\title{
The immune modulatory effects of umbilical cord-derived mesenchymal stromal cells in severe COVID-19 pneumonia
}

Rachele Ciccocioppo ${ }^{1 *+} \mathbb{D}$, Davide Gibellini ${ }^{2 \dagger}$, Giuseppe Astori ${ }^{3}$, Martina Bernardi ${ }^{3}$, Angela Bozza ${ }^{3}$, Katia Chieregato ${ }^{3}$, Francesca Elice ${ }^{4}$, Stefano Ugel ${ }^{5}$, Simone Caligola ${ }^{5}$, Francesco De Sanctis ${ }^{5}$, Stefania Canè ${ }^{5}$, Alessandra Fiore ${ }^{5}$, Rosalinda Trovato ${ }^{5}$, Antonio Vella ${ }^{5}$, Varvara Petrova ${ }^{5}$, Giuseppe Amodeo ${ }^{1}$, Monica Santimaria ${ }^{6}$, Annarita Mazzariol ${ }^{2}$, Luca Frulloni ${ }^{1}$, Marco Ruggeri ${ }^{4}$, Enrico Polati ${ }^{7}$ and Vincenzo Bronte ${ }^{5}$

\begin{abstract}
Coronavirus disease 2019 (COVID-19) may result in a life-threatening condition due to a hyperactive immune reaction to severe acute respiratory syndrome-coronavirus-2 infection, for which no effective treatment is available. Based on the potent immunomodulatory properties of mesenchymal stromal cells (MSCs), a growing number of trials are ongoing. This prompted us to carry out a thorough immunological study in a patient treated with umbilical cord-derived MSCs and admitted to the Intensive Care Unit for COVID-19-related pneumonia. The exploratory analyses were assessed on both peripheral blood and bronchoalveolar fluid lavage samples at baseline and after cellular infusion by means of single-cell RNA sequencing, flow cytometry, ELISA, and functional assays. Remarkably, a normalization of circulating T lymphocytes count paralleled by a reduction of inflammatory myeloid cells, and a decrease in serum levels of pro-inflammatory cytokines, mostly of interleukin- 6 and tumor necrosis factor-a, were observed. In addition, a drop of plasma levels of those chemokines essential for neutrophil recruitment became evident that paralleled the decrease of lung-infiltrating inflammatory neutrophils. Finally, circulating monocytes and low-density gradient neutrophils acquired immunosuppressive function. This scenario was accompanied by an amelioration of respiratory, renal, inflammatory, and pro-thrombotic indexes. Our results provide the first immunological data possibly related to the use of umbilical cord-derived MSCs in severe COVID-19 context.
\end{abstract}

Keywords: COVID-19, Cytokines, Inflammatory response, Mesenchymal stromal cells, ScRNA-seq

\footnotetext{
* Correspondence: rachele.ciccocioppo@univr.it

${ }^{\dagger}$ Rachele Ciccocioppo and Davide Gibellini contributed equally to this work. ${ }^{1}$ Gastroenterology Unit, Department of Medicine, A.O.U.I. Policlinico G.B. Rossi \& University of Verona, Piazzale L.A. Scuro, 10, 37134 Verona, Italy Full list of author information is available at the end of the article
}

C C The Author(s). 2021 Open Access This article is licensed under a Creative Commons Attribution 4.0 International License, which permits use, sharing, adaptation, distribution and reproduction in any medium or format, as long as you give appropriate credit to the original author(s) and the source, provide a link to the Creative Commons licence, and indicate if changes were made. The images or other third party material in this article are included in the article's Creative Commons licence, unless indicated otherwise in a credit line to the material. If material is not included in the article's Creative Commons licence and your intended use is not permitted by statutory regulation or exceeds the permitted use, you will need to obtain permission directly from the copyright holder. To view a copy of this licence, visit http://creativecommons.org/licenses/by/4.0/. The Creative Commons Public Domain Dedication waiver (http://creativecommons.org/publicdomain/zero/1.0/) applies to the data made available in this article, unless otherwise stated in a credit line to the data. 


\section{Introduction}

In a variable proportion of cases, severe acute respiratory syndrome-coronavirus (SARS-CoV)-2 infection triggers a hyperacute inflammatory response that may ultimately lead to respiratory and multiorgan failure [1]. The immunological hallmarks comprise lymphopenia [2] and a flurry of active molecules which gives rise to the socalled "cytokine storm" [3], largely dominated by interleukin (IL)-6 and tumor necrosis factor (TNF)- $\alpha$ [4]. This causes disruption of both epithelial and endothelial barriers that magnifies inflammation and hampers gas exchange [5]. Despite there currently being a number of therapeutic approaches under investigation [6], none have substantially changed patients' outcome. Following the results of early studies carried out in China showing the safety of applying mesenchymal stromal cells (MSCs) in patients with moderate to severe COVID-19-related pneumonia $[7,8]$, we offered this option to a patient admitted to the Intensive Care Unit for COVID-19 respiratory failure and unresponsive to current therapy. The rationale of this option lies on the evidence of a powerful and multifaceted action of MSCs on virtually all cell populations involved in inflammatory cascade [9]. Noteworthy, MSCs have also proven of benefit in experimental studies on acute respiratory distress syndrome [10], while the safety of this treatment option has been shown in a phase $2 \mathrm{a}$ trial carried out in this clinical setting [11]. Although these findings point to a potential role of MSCs even in COVID-19, no information is available on their immunological effects in this specific clinical setting. Therefore, we carried out an in-depth immune profiling at both bronchoalveolar and circulating levels to move the first step towards the understanding of their therapeutic effects in this dismal condition.

\section{Methods}

\section{Mesenchymal stromal cell administration}

The advanced cell therapy medicinal product was supplied by the Laboratory for Advanced Cellular Therapies (Vicenza, Italy) in two bags as frozen, sterile, apyrogenic umbilical cord-derived MSC suspension (see Supplementary material). Upon receiving, the bags were thawed in succession under sterile conditions, diluted 1:1 $(50 \mathrm{ml}$ final) in a solution consisting of $38 \%$ saline, $10 \%$ human albumin, and $12 \%$ anticoagulant citrate dextrose solution (Terumo; Rome, Italy), connected to an infusion set, delivered to the Intensive Care Unit and then infused intravenously in $30 \mathrm{~min}$ each (Fig. 1a). The final dosage was of $1.1 \times 10^{6}$ cells/per $\mathrm{kg}$ body weight, in accordance with that used either in an early study on COVID-19 patients [7], or in further immune-mediated conditions, such as graft-versus-host disease [12, 13], and on personal experience $[14,15]$. The patient was a 69 -year-old Caucasian man who had been admitted to the Intensive
Care Unit (A.O.U.I. Ospedale Maggiore; Verona, Italy) 2 weeks earlier for respiratory failure due to diagnosis of COVID-19 (see Supplementary material) pneumonia. The lack of amelioration upon a course of anti-viral agents (lopinavir-ritonavir) plus hydroxychloroquine and steroids, together with antiaggregant/coagulant therapy, vasoactive agents and nine rounds of prono-supination, and the failure at the screening assessment for further experimental therapies led us to offer him MSC infusion under the Hospital Exemption rule (art. 28 European Regulation 1394/2007), after approval by both the local Ethics Committee (no. 19464) and the Italian Drug Agency (no. 163516409) was obtained, and upon both the consent to participate and for publication were obtained by a relative since the patient was under pharmacological coma. The immunological analyses were performed on both bronchoalveolar lavage fluid (BALF) and peripheral blood samples before and after MSC infusion (Fig. 1a). Specifically, we decided to split the analyses using two different timeframes by considering that cytokines display a short life-span (estimated of hours), while circulating cell composition and myeloid cell function require a shift on myelopoiesis that need longer times (estimated of days). In parallel, a number of clinical and laboratory parameters were also assessed.

\section{Single-cell RNA sequencing}

After isolation of immune cells from both BALF and peripheral blood samples (see Supplementary material) at baseline and after 2 days from MSC infusion, the single-cell RNA sequencing was carried out on 12,000 cells after reverse transcription, cDNA amplification, and library construction were performed (see Supplementary material). Sequencing, alignment, barcode processing, and unique molecular identifier quantification were then assessed after checking the sample quality. Following integration and normalization of collected data [16], the clustering analysis was built up and the Wilcoxon rank-sum test was used for computing the statistically significant difference (see Supplementary material). Analysis was performed at baseline and after 2 days from MSC infusion.

\section{Flow cytometry}

Peripheral blood cell immunophenotyping was performed at baseline and 8 days after MSC infusion according to a standard no-wash procedure, using a PrepPlus $^{\mathrm{TM}} 2$ workstation (Beckman Coulter Inc.; Brea, CA, USA) by incubating the samples for $15 \mathrm{~min}$ at $20{ }^{\circ} \mathrm{C}$ with a panel of antibodies (all by Beckman Coulter Inc.) as listed in Supplementary material. Cytofluorimetric characterization of circulating immune cells was performed at baseline and after 8 days from MSC infusion. 




\section{Detection of cytokines and serology}

The following cytokines: IL-1 $\beta$, IL-1RA, IL-2, IL-6, IL-8, IL-10, IL-15, interferon (IFN)- $\gamma$, TNF- $\alpha$, vascular endothelial growth factor-A, and chemokines/ligands, CCL2, CCL3, CCL5, CXCL10, and CXCL12, were detected and quantified in the patient's serum at baseline and after 2 days from MSC infusion by using the
Human ProcartaPlex ${ }^{\text {Tw }}$ Panel 1 multiplex kit (Thermo Fisher Scientific; Waltham, MA, USA). Cytokine serum levels were detected at baseline and after 2 days from MSC infusion.

The ELISA assay to detect immunoglobulins (Ig) used fragment of the SARS-CoV2 spike glycoprotein (S-protein) as recently published [17]. 


\section{Functional assay}

Upon Ficoll-Hypaque (GE Healthcare; Uppsala, Sweden) gradient centrifugation of peripheral blood samples harvested at baseline and 8 days after MSC infusion, monocytes and low-density gradient neutrophils (LDNs) were isolated by using CD14-microbeads (Miltenyi Biotec; Bergisch Gladbach, DE), and the sequential addition of CD66b-FITC antibody (BD Biosciences; NJ, USA) and microbeads anti-FITC (Miltenyi), respectively, following the manufacturers' instructions. The purity of each fraction was evaluated at flow cytometry and a minimum cutoff of $95 \%$ was needed to perform the immunosuppressive assay [18]. A sample of $2 \times 10^{6}$ cells of each cell type was seeded in 24-well plates for $12 \mathrm{~h}$; afterwards, both the supernatants and cells were collected and cultured with CellTrace (Thermo Fisher Scientific; Waltham, MA, USA). Labeled cells were then stimulated with coated anti-CD3 (OKT-3) and soluble anti-CD28 for 4 days at $37{ }^{\circ} \mathrm{C}$ in $8 \% \mathrm{CO}_{2}$. For the co-cultures, a 3:1 (target to effector) ratio was used. Cells were finally stained with anti-CD3-PE/Cy7 and CellTrace signal was analyzed with FlowJo software (Tree Star, Inc., Ashland). This analysis was performed at baseline and after 8 days from infusion.

\section{Results}

\section{Clinical findings}

Although SARS-CoV-2 $\mathrm{N}$ gene was detected in BALF samples at very high cycle threshold throughout the observational period, an improvement of the inflammatory, respiratory, thrombotic, and renal parameters was observed after 2 and 8 days after MSC infusion (Table 1). No adverse events occurred during the same time frame. In addition, neither the serum level of class A and G immunoglobulins specific for the receptor-binding domain of the SARS-CoV-2 spike protein nor that of class G antibodies recognizing the nucleocapsid phosphoprotein of the virus underwent modification (Fig. 1b).

Notably, at baseline, the patient was in respiratory acidosis $\left(\mathrm{pH}, 7.31 ; \mathrm{PCO}_{2}, 57 \mathrm{mmHg} ; \mathrm{BE}, 1.70 ; \mathrm{HCO}_{3}{ }^{-}\right.$, $28.7 \mathrm{mmol} / \mathrm{L}$ ), partially compensated by metabolic alkalosis on the second day $\left(\mathrm{pH}, 7.34 ; \mathrm{PCO}_{2}, 61 \mathrm{mmHg}\right.$; $\mathrm{BE}$, 5.9; $\mathrm{HCO}_{3}{ }^{-}, 32.9 \mathrm{mmol} / \mathrm{L}$ ). Then, the patient underwent continuous infusion of furosemide which led to a mixed clinical picture of metabolic alkalosis and respiratory acidosis, as exemplified by parameters of day $8(\mathrm{pH}$, 7.38; $\left.\mathrm{PCO}_{2}, 70 \mathrm{mmHg} ; \mathrm{BE}, 14.2 ; \mathrm{HCO}^{-}, 41.4 \mathrm{mmol} / \mathrm{L}\right)$.

\section{Single-cell RNA sequencing of lung immune microenvironment}

At total of 6362 high-quality single-cell transcriptomes for BALF cells were assessed and the overall population structure was visualized in two-dimensional space using Uniform Manifold Approximation and Projection
Table 1 Clinical parameters

\begin{tabular}{|c|c|c|c|}
\hline & Day 0 & Day + 2 & Day +8 \\
\hline SOFA score & 4 & 3 & 3 \\
\hline Creatinine & 2.27 & 0.99 & 0.90 \\
\hline $\mathrm{HCO}_{3}{ }^{-}$ & 28.7 & 32.9 & 41.4 \\
\hline D-Dimer & 3.83 & 2.68 & 1.32 \\
\hline Prothrombin time & 1.18 & 1.09 & 0.96 \\
\hline $\mathrm{P} / \mathrm{F}$ & 168 & 136 & 114 \\
\hline $\mathrm{FiO}_{2}$ & 0.50 & 0.50 & 0.70 \\
\hline $\mathrm{pH}$ & 7.31 & 7.34 & 7.38 \\
\hline Base excess & 1.70 & 5.90 & 14.2 \\
\hline White blood cells & 11.19 & 10.14 & 8.62 \\
\hline Neutrophils & 9.29 & 8.28 & 6.59 \\
\hline Lymphocytes & 1.01 & 1.11 & 1.21 \\
\hline Monocytes & 0.37 & 0.44 & 0.40 \\
\hline Basophils & 0.06 & 0.05 & 0.04 \\
\hline Eosinophils & 0.46 & 0.26 & 0.38 \\
\hline Red blood cells & 4.16 & 4.13 & 3.91 \\
\hline Platelet & 365 & 327 & 287 \\
\hline C-reactive protein & 201 & 139 & 61 \\
\hline
\end{tabular}

SOFA Sequential Organ Failure Score, $P / F$ oxygen partial pressure/oxygen inspiratory flow, $\mathrm{FiO}_{2}$ oxygen inspiratory flow

Normal values: creatinine, $0.49-1.19 \mathrm{mg} / \mathrm{dL}_{;} \mathrm{HCO}_{3}{ }^{-}, 24-28 \mathrm{mmol} / \mathrm{L} ; \mathrm{D}-\mathrm{Dimer},<$ $0.25 \mathrm{mg} / \mathrm{L}$; prothrombin time, 0.8-1.17 INR\%; P/F, > $300 \mathrm{mmHg} ; \mathrm{FiO}_{2},>21 \%$; $\mathrm{pH}, 7.35-7.45$; base excess, -2 to $+2 \mathrm{mmol} / \mathrm{L}$; white blood count, $4.30-10 \times$ $10^{9} / \mathrm{L}$; neutrophils, $1.80-8 \times 10^{9} / \mathrm{L}$; lymphocytes, $1.20-4 \times 10^{9} / \mathrm{L}$; monocytes, $0.20-1 \times 10^{9} / \mathrm{L}$; basophils, $<0.20 \times 10^{9} / \mathrm{L}$; eosinophils, $<0.45 \times 10^{9} / \mathrm{L}$; red blood count, $4.00-5.20 \times 10^{12} / \mathrm{L}$; platelet, $150-450 \times 10^{9} / \mathrm{L}$; C-reactive protein, $<5 \mathrm{mg} / \mathrm{L}$

(Fig. 1c). The unsupervised analysis identified six major clusters that were assigned to neutrophils $\left(\mathrm{FCGR}^{+} \mathrm{B}^{+}\right.$, $\mathrm{CSF}^{+} \mathrm{R}^{+}$, macrophages $\left(\mathrm{CD}^{2} 8^{+}, \mathrm{FCGR}^{+} \mathrm{A}^{+}, \mathrm{CD} 14^{+}\right)$, $\mathrm{CD}^{+} \mathrm{T}$ cells $\left(\mathrm{CD} 3 \mathrm{D}^{+}, \mathrm{CD}^{+} \mathrm{A}^{+}, \mathrm{CD}^{+} \mathrm{B}^{+}\right), \mathrm{CD}^{+} \mathrm{T}$ cells $\left(\mathrm{CD}^{+} \mathrm{D}^{+}, \mathrm{CD} 4^{+}\right)$, natural killer $(\mathrm{NK})$ cells $\left(\mathrm{FCGR}^{+} \mathrm{A}^{+}\right.$, $\mathrm{KLRD}^{+}$), and $\mathrm{KRT}_{1} 8^{+}$epithelial cells (Fig. 1d). In line with previously reported data on severe COVID-19 patients [19], BALF contained high proportions of neutrophils and macrophages with very limited number of $\mathrm{T}$ lymphocytes and NK cells (Fig. 1c). Notably, the frequency of lung-infiltrating immune cell populations did not substantially change during the observational time (Fig. 1d). However, a robust change became evident at a deeper analysis of neutrophils (Fig. 1e) since, according to the expression of typical markers, we identified two clusters of highly inflammatory neutrophils $\left(\mathrm{S} 100^{+}\right.$neutro and $\mathrm{CCL}^{+}$neutro), one cluster of IFN-activated neutrophils (ISGs, GBPs) expressing CD274 (PD-L1) and one containing stressed/exhausted cells characterized by the production of heat shock proteins $\left(\mathrm{HSP}^{+}\right.$neutro), together with a small cluster of immature neutrophils $\left(\mathrm{CD} 16^{-}, \mathrm{CD}^{-} 0^{-}\right)$expressing IRAK3 (IRAK3 $^{+}$neutro) 
(Fig. 1e). Interestingly, the frequency of highly inflammatory clusters along with the immature one underwent reduction after MSC infusion whereas a slight increase of the other two clusters occurred during the same interval (Fig. 1f).
Single-cell RNA sequencing of circulating immune cells A total of 3762 single-cell transcriptomes of peripheral blood cells were analyzed. The overall representation of each population showed 10 different clusters (Fig. 2a) and top three genes expressed in each cluster (Fig. 2b).




Again, very few lymphoid cells were found in the following clusters: NK cells $\left(\mathrm{FCGR}^{+} \mathrm{A}^{+}, \mathrm{KLRD}^{+}, \mathrm{GZMA}^{+}\right.$, $\left.\mathrm{GZMB}^{+}\right), \mathrm{CD}^{+} \mathrm{T}$ cells, $\mathrm{T}$ cells $\left(\mathrm{CD}^{+}, \mathrm{CD}^{+}\right)$, and $\mathrm{B}$ cells $\left(\mathrm{MS}_{\mathrm{A}} \mathrm{A}^{+}\right)$. The myeloid compartment was predominantly composed by classic monocytes $\left(\mathrm{CD} 14^{+}\right)$, inflammatory neutrophils $\left(\mathrm{FCGR} \mathrm{B}^{+}\right)$, a small cluster of non-classic monocytes, and neutrophil precursors $\left(\mathrm{CEACAM}^{+}, \mathrm{ARG1}^{+}, \mathrm{MPO}^{+}\right)$. Interestingly, circulating neutrophils were mostly denoted by FCGR3B, CXCR2, and CSF3R resembling the BALF cluster of highly inflammatory neutrophils $\left(\mathrm{S}_{100^{+}}\right.$neutro) (Fig. 2c) in line with previous reports [20,21]. As shown in Fig. 2d, after MSC infusion, a contraction of the absolute number of circulating leukocytes occurred, mostly due to a decrease in neutrophils as well as NK and NKT cells, as evident at flow cytometry. By contrast, $\mathrm{T}$ cells increased as effect of expansion of both $\mathrm{CD}^{+}$and $\mathrm{CD} 4^{+}$subsets, mostly central memory $\mathrm{CD}^{+} \mathrm{T}$ cells $\left(\mathrm{CD}^{+}, \mathrm{CD}^{+}, \mathrm{CD} 27^{+}\right.$, $\left.\mathrm{CD}^{2} 5 \mathrm{RA}^{-}\right)$and effector memory $\mathrm{CD}^{+} \mathrm{T}$ cells $\left(\mathrm{CD}^{+}\right.$, $\mathrm{CD}^{+}, \mathrm{CD}^{2} 5 \mathrm{RA}^{-}, \mathrm{CD} 7^{+}$), paralleled by a concurrent drop in naïve $\mathrm{CD}^{+} \mathrm{T}$ cells $\left(\mathrm{CD}^{+}, \mathrm{CD}^{+}, \mathrm{CD} 27^{+}\right.$, $\left.\mathrm{CD} 4 \mathrm{RA}^{+}\right)$. Notably, a redistribution of monocyte subsets did occur since an increase of the absolute number of non-classic and intermediate monocytes and a decrease of classic ones were observed. By contrast, B-cell population was barely affected by MSC infusion.

In parallel, a critical reduction of IL-1 $\beta$, IL-1RA, IL-6, and TNF- $\alpha$ concentration was evident 2 days after MSC infusion, mimicking the effectiveness of other immunomodulatory agents, such as baricitinib [17], in dampening COVID-19-associated inflammation. Moreover, a decrease in IL-10 in combination with an opposite trend for IL-2, IL-15, and IFN- $\gamma$ was detected during the same time frame, strengthening the idea that MSCs might fuel a favorable environment for T-cell proliferation (Fig. 3a), as indeed found (Fig. 2d). In addition, we identified increased levels of CCL2 (an essential chemokine for both monocyte and memory $\mathrm{CD}^{+} \mathrm{T}$-cell migration and function), CCL5 (a potent chemoattractant for effector memory $\mathrm{CD}^{+}{ }^{+} \mathrm{T}$ cells), and CXCL10 (an IFN- $\gamma$-inducible protein associated with type $1 \mathrm{~T}$-cell response) [22] (Fig. 3b). By contrast, a drop on plasma levels of such chemokines (CCL3, IL-8, and CXCL12) essential for neutrophil recruitment [22] was clearly evident (Fig. 3b). These data might explain the decrease of lunginfiltrating inflammatory neutrophils $\left(\mathrm{S} 100^{+}\right.$neutro and $\mathrm{CCL}^{+}$neutro) emerging from the single-cell RNA sequencing (Fig. 1f).

\section{Functional assay}

Because the in vivo therapeutic effects of MSCs have been related to the ability of endogenous phagocytes to engulf apoptotic MSCs and activate an immunomodulatory program [23], we also performed an in vitro assay by using circulating monocytes (CD14 ${ }^{+}$cells) and LDNs harvested before and 8 days after MSC infusion. As shown in Fig. 3c, monocytes acquired the ability to suppress T-cells. This immunosuppressive feature seemed related to the increase of arginase1-expressing non-classic monocytes (Fig. 3d). Similarly, LDNs also acquired immunosuppressive properties (Fig. 3e), while their count gradually expanded (Fig. 3f).

\section{Discussion}

Reversing of the "cytokine storm" appears a key strategy to counterattack COVID-19 pneumonia [1, 24]. MSCs have been widely explored as a new treatment option for a number of immune-mediated conditions, including acute steroid-refractory graft-versus-host disease, where a "cytokine storm" is responsible for the high mortality rate [25]. It is conceivable, therefore, that MSCs may also have positive effects on the "cytokine storm" observed in critically ill COVID-19 patients. Therefore, we decided to treat a patient under mechanical ventilation for COVID-19-related respiratory failure with umbilical cord-MSCs under the Hospital Exemption rule. It is recognized that upon intravenous administration, MSCs lodge in the pulmonary vascular bed, where the majority of them are cleared within 24-48 h [26], although there can be longer persistence in inflamed lungs [27]. This is why we chose to analyze the immunological parameters before and after 2 and 8 days after MSC infusion, on the basis of their estimated half-life. While trapped in the lungs, MSCs are able to release a wide array of bioactive molecules, including anti-inflammatory cytokines [28], antimicrobial peptides [29], angiogenic growth factors, and extracellular vesicles [30], that guarantee the phenotypic and functional shift of both epithelial and immune cells [31, 32]. Moreover, despite the fact that the effects of systemic MSC administration in animal models of influenza respiratory infections are under debate [33], systemic infusion of MSCs in a mouse model of lipopolysaccharide-induced ARDS significantly ameliorated alveolar injury and inflammation [34]. In line with this evidence, further studies showed that MSCs promoted the regeneration of alveolar epithelial type II cells, prevented the apoptosis of endothelial cells, and contributed to the enhanced repair of the alveolar epithelial barrier in the ARDS-injured lungs [35-37]. Although we cannot exclude that the modification observed upon MSC treatment was unrelated to cellular therapy, it is conceivable that the reduction of the levels of chemokines and inflammatory cytokines in serum samples (Fig. 3a, b) and the contraction of pro-inflammatory neutrophil subset at pulmonary system (Fig. 1e, f) mirrored by an improvement of gas exchange and clinical parameters were the direct or indirect effects of MSC action. Moreover, our data suggest that MSCs 


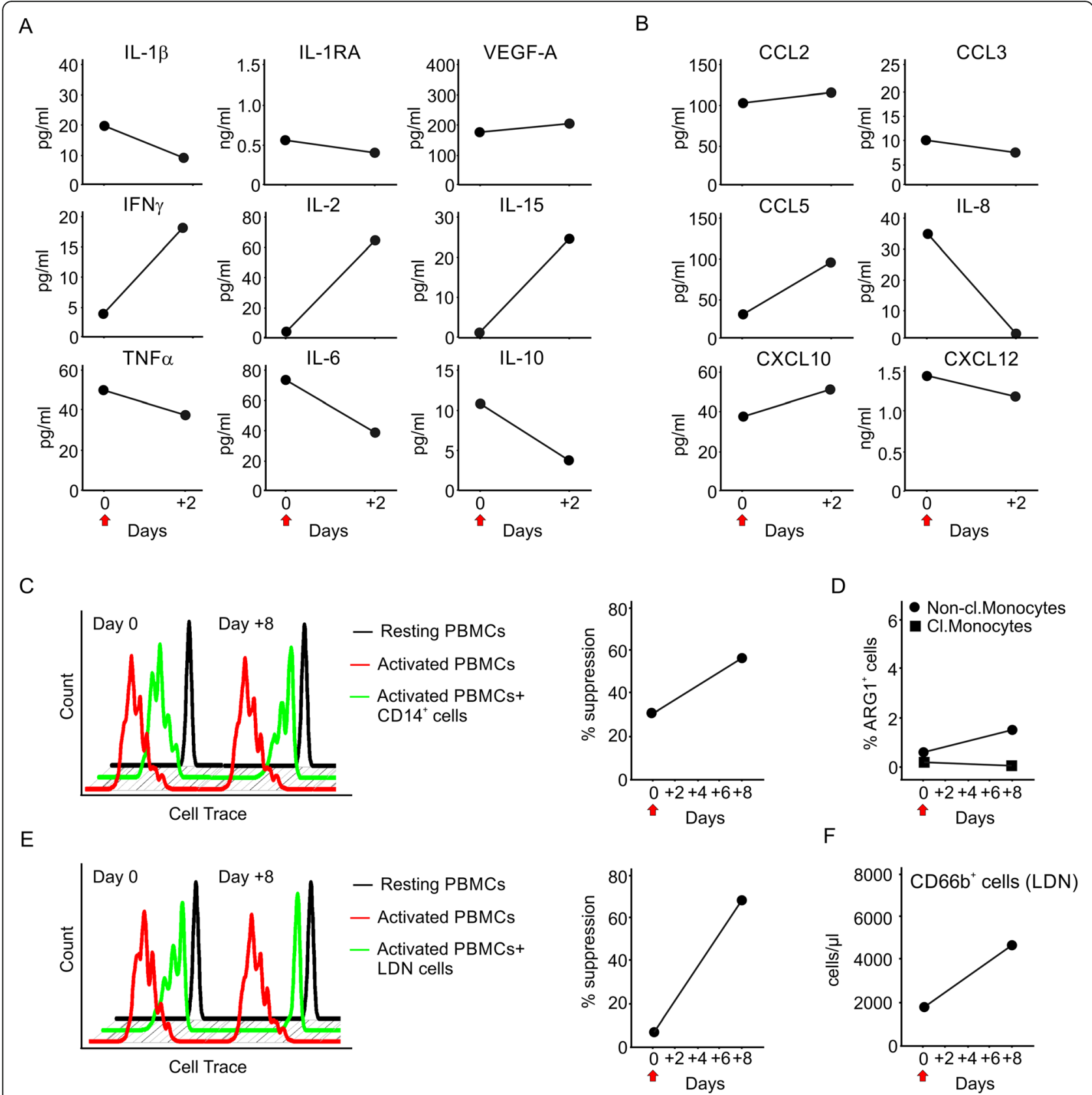

Fig. 3 Plasma cytokine/chemokine profile, and functional assay. a Plasma levels of cytokines at days 0 and +2 after MSC infusion. b Plasma levels of chemokines at days 0 and +2 after MSC infusion. c The immune suppressive ability of monocytes was tested in functional assay on activated $\mathrm{T}$ cells and shown as percentage of suppression. $\mathbf{d}$ Arginase $1^{+}$cells within the monocytes subsets were evaluated by flow cytometry at different time points. e The immune suppressive ability of $C D 66 b^{+}$LDNs was tested in functional assay on activated T cells and shown as percentage of suppression. $\mathbf{f} L D N s$ were counted and reported as number of cells/ $\mu \mathrm{l}$. The red arrow indicates the time point in which MSC infusion was performed. For comments, see the text. CCL, C-C motif chemokine ligand; CXCL, C-X-C motif chemokine ligand; Cl., classic; IL, interleukin; IFN, interferon; IL-1RA, interleukin-1 receptor A; LDN, low-density gradient neutrophil; MSC, mesenchymal stromal cell; PBMC, peripheral blood mononuclear cell; TNF, tumor necrosis factor; VEGF, vascular endothelial growth factor

administration was temporally associated with the development of favorable microenvironment for T-cell proliferation, while restraining the accumulation of proinflammatory neutrophils that could have actively fueled inflammation during the disease progression. In addition, monocytes underwent re-programming towards the intermediate/non-classical phenotype, a subset with more immunomodulatory function [38] and a higher propensity to become dendritic cells with a strong capacity to induce T-cell proliferation $[39,40]$. 
This is an important point since there is growing evidence showing the relevant role played by monocytes in MSC-driven immunomodulation [41]. Further, our in vitro assay showed the ability of both monocytes and LDNs to acquire immunosuppressive abilities upon MSC treatment. In this regard, it should be emphasized that an expansion of arginase1-expressing CD14+ cells was found, a monocyte subset that we recently identified as immunosuppressive elements in pancreatic cancer patients [42].

However, an important question that remains to be solved is whether protective MSC effects are directly against viral infection, perhaps by stimulating specific anti-viral T-cell action, or whether they are due to overall anti-inflammatory effects. Following the persistence of detectable levels of the $\mathrm{N}$ gene in the patient's BALF samples, it is likely that MSCs favor the development of an anti-inflammatory and protective environment able to dampen the "cytokine storm" while contributing to the restoration of alveolar-capillary barrier, instead of having a direct anti-viral effect.

Although the data presented here were obtained from a single patient, the completeness and depth of the immunological analyses carried out reinforces the idea of an altered myeloid compartment in the specific setting of COVID-19 severe pneumonia [21]. Moreover, the parameters identified may be of meaningful clinical utility as a potential platform to identify key biomarkers to design consistent and informative clinical trials on the use of MSC therapy in this dismal condition.

\author{
Abbreviations \\ BALF: Bronchoalveolar lavage fluid; CCL: C-C motif chemokine ligand; \\ CXCL: C-X-C motif chemokine ligand; COVID: Coronavirus disease; \\ IFN: Interferon; IL: Interleukin; LDNs: Low-density neutrophils; \\ MSC: Mesenchymal stromal cell; NK: Natural killer; SARS-CoV: Severe acute \\ respiratory syndrome-coronavirus; TNF: Tumor necrosis factor
}

\section{Supplementary Information}

The online version contains supplementary material available at https://doi. org/10.1186/s13287-021-02376-9.

Additional file 1: Supplementary methods.

\section{Acknowledgements}

We dedicate this work to the memory of all the health care professionals who gave their lives in the care of patients with COVID-19. We thank all the personnel involved in patient care and assistance. We also thank the members of the Immunology Section at the A.O.U.I. Policlinico G.B. Rossi in Verona (Italy) who actively worked during the pandemic: Cristina Anselmi, Roza Maria Barouni, Monica Brentegani, Nadia Brutti, Tiziana Cestari, Elena Chiesa, Giulio Fracasso, Cristina Frusteri, Oretta Gabrielli, Elisabetta Gallo, Francesca Hofer, Elena Lucchini, Morena Martini, Chiara Musiu, Fiorenza Paiola, Laura Pinton, Cristina Frusteri, Annalisa Adamo, Claudia Pizzoli, and Ornella Poffe for the excellent technical work; Selena Gomirato, Riccardo Ortolani, Silvia Sartoris, and Giovanna Zanoni for their help with the management of immunological data; and Claudia Italia, Daniel Lovato, and Antonella Valentini for the administrative support. We are also grateful to the mother who kindly donated the umbilical cord and to the nurses of the Obstetrics and
Gynecology Unit of the Arzignano Hospital (Vicenza, Italy) for the collection of the umbilical cord.

\section{Authors' contributions}

RC: conception and design, full responsibility for cell therapy, data analysis and interpretation, manuscript writing, and final approval of the manuscript. DG: financial support, data analysis and interpretation, and final approval of the manuscript. GAs: full responsibility of manufacturing, testing and quality control of the advanced cell therapy medicinal product, manuscript writing, and final approval of the manuscript. MB: manufacturing, testing and quality control of the advanced cell therapy medicinal product, and final approval of the manuscript. AB: manufacturing, testing and quality control of the advanced cell therapy medicinal product, and final approval of the manuscript. KC: manufacturing, testing and quality control of the advanced cell therapy medicinal product, and final approval of the manuscript. FE: supervision of advanced cell therapy medicinal product administration and final approval of the manuscript. SU: collection and assembly of data, data analysis and interpretation, manuscript writing, and final approval of the manuscript. SCal: data analysis and interpretation, manuscript writing, and final approval of the manuscript. FDS: collection and assembly of data, data analysis and interpretation, and final approval of the manuscript. SCan: collection and assembly of data, data analysis and interpretation, and final approval of the manuscript. AF: collection and assembly of data, data analysis and interpretation, and final approval of the manuscript. RT: collection and assembly of data, data analysis and interpretation, manuscript writing, and final approval of the manuscript. AV: collection and assembly of data, data analysis and interpretation, and final approval of the manuscript. VP: collection and assembly of data, data analysis and interpretation, and final approval of the manuscript. GAm: collection and analysis of clinical data and final approval of the manuscript. MS: regulatory support and final approval of the manuscript. AM: collection and assembly of data, data analysis and interpretation, and final approval of the manuscript. LF: critical revision of the manuscript and final approval of the manuscript. MR: critical revision of the manuscript and final approval of the manuscript. EP: patient's care and final approval of the manuscript. VB: conception and design, financial support, data analysis and interpretation, manuscript writing, and final approval of the manuscript.

\section{Funding}

This study was supported by a research grant from Fondazione CariVerona entitled: "ENACT" to Vincenzo Bronte and Davide Gibellini, and Fondazione TIM to Vincenzo Bronte. This source of funding was not in any way involved in the study design, collection, analysis and interpretation of data, writing of the manuscript, or in the decision to submit the article for publication.

\section{Availability of data and materials}

The data that support the findings of this study are available from the corresponding author upon reasonable request.

\section{Declarations}

Ethics approval and consent to participate

The study was conducted according to the Hospital Exemption rule (art. 28 European Regulation 1394/2007) and after approval by both the local Ethics Committee (no. 19464) and the Italian Drug Agency (no. 163516409). Informed consent was obtained by a relative because of the patient was under pharmacological coma.

\section{Consent for publication}

Consent for publication of the data was obtained by a relative because of the patient was under pharmacological coma.

\section{Competing interests}

The authors declare that they have no competing interests.

\section{Author details}

'Gastroenterology Unit, Department of Medicine, A.O.U.I. Policlinico G.B. Rossi \& University of Verona, Piazzale L.A. Scuro, 10, 37134 Verona, Italy. ${ }^{2}$ Microbiology Section, Department of Diagnostics and Public Health, University of Verona, Verona, Italy. ${ }^{3}$ Laboratory of Advanced Cellular Therapies, Hematology Unit, San Bortolo Hospital, A.U.L.S.S. 8 "Berica", 
Vicenza, Italy. ${ }^{4}$ Hematology Unit, San Bortolo Hospital, A.U.L.S.S. 8 "Berica", Vicenza, Italy. Immunology Unit, Department of Medicine, A.O.U.I. Policlinico G.B. Rossi \& University of Verona, Verona, Italy. ${ }^{6}$ Nuclear Medicine Unit, San Bortolo Hospital, A.U.L.S.S. 8 "Berica", Vicenza, Italy. 'Intensive Care Unit, Department of Surgery, Dentistry, Maternity and Infant, A.O.U.I. Ospedale Maggiore \& University of Verona, Verona, Italy.

\section{Received: 27 November 2020 Accepted: 9 May 2021}

\section{Published online: 02 June 2021}

\section{References}

1. Vabret N, et al. Immunology of COVID-19: current state of the science. Immunity. 2020;52(6):910-41. https://doi.org/10.1016/j.immuni.2020.05.002.

2. Tan L, et al. Lymphopenia predicts disease severity of COVID-19: a descriptive and predictive study. Signal Transduct Target Ther. 2020;5(1):33. https://doi.org/10.1038/s41392-020-0148-4.

3. Gao Y-M, Xu G, Wang B, Liu B-C. Cytokine storm syndrome in coronavirus disease 2019: a narrative review. J Intern Med. 2020, 2021;10. https://doi. org/10.1111/joim.13144.

4. Giamarellos-Bourboulis EJ, Netea MG, Rovina N, Akinosoglou K, Antoniadou A, Antonakos N, et al. Complex immune dysregulation in COVID-19 patients with severe respiratory failure. Cell Host Microbe. 2020;27(6):992-1000. https://doi.org/10.1016/j.chom.2020.04.009.

5. Vardhana SA, Wolchok JD. The many faces of the anti-COVID immune response. J Exp Med. 2020;217(6):e20200678. https://doi.org/10.1084/jem.202 00678.

6. Wu R, et al. An update on current therapeutic drugs treating COVID-19. Curr Pharmacol Rep. 2020. https://doi.org/10.1007/s40495-020-00216-7.

7. Leng Z, et al. Transplantation of ACE2(-) mesenchymal stem cells improves the outcome of patients with COVID-19 pneumonia. Aging Dis. 2020;11(2): 216-28. https://doi.org/10.14336/AD.2020.0228.

8. Meng F, Xu R, Wang S, Xu Z, Zhang C, Li Y, et al. Human umbilical cordderived mesenchymal stem cell therapy in patients with COVID-19: a phase 1 clinical trial. Signal Transduct Target Ther. 2020;5(1):172. https://doi.org/1 0.1038/s41392-020-00286-5.

9. Zhao RC. Stem cell-based therapy for coronavirus disease 2019. Stem Cells Dev. 2020;29(11):679-81. https://doi.org/10.1089/scd.2020.0071.

10. McIntyre LA, et al. Efficacy of mesenchymal stromal cell therapy for acute lung injury in preclinical animal models: a systematic review. Plos One. 2016; 11(1):e0147170. https://doi.org/10.1371/journal.pone.0147170.

11. Matthay MA, Calfee CS, Zhuo H, Thompson BT, Wilson JG, Levitt JE, et al. Treatment with allogeneic mesenchymal stromal cells for moderate to severe acute respiratory distress syndrome (START study): a randomised phase 2a safety trial. Lancet Respir Med. 2019;7(2):154-62. https://doi.org/1 0.1016/S2213-2600(18)30418-1.

12. Muroi K, Miyamura K, Okada M, Yamashita T, Murata M, Ishikawa T, et al. Bone marrow-derived mesenchymal stem cells (JR-031) for steroid-refractory grade III or IV acute graft-versus-host disease: a phase II/III study. Int J Hematol. 2016;103(2):243-50. https://doi.org/10.1007/s12185-015-1915-9.

13. Zhao K, Lou R, Huang F, Peng $Y$, Jiang $Z$, Huang $K$, et al. Immunomodulation effects of mesenchymal stromal cells on acute graft-versus-host disease after hematopoietic stem cell transplantation. Biol Blood Marrow Transplant. 2015;21(1):97-104. https://doi.org/10.1016/ j.bbmt.2014.09.030.

14. Ciccocioppo R, Russo ML, Bernardo ME, Biagi F, Catenacci L, Avanzini MA, et al. Mesenchymal stromal cell infusions as rescue therapy for corticosteroid-refractory adult autoimmune enteropathy. Mayo Clin Proc. 2012;87(9):909-14. https://doi.org/10.1016/j.mayocp.2012.04.014.

15. Ciccocioppo R, Gallia A, Avanzini MA, Betti E, Picone C, Vanoli A, et al. A refractory celiac patient successfully treated with mesenchymal stem cel infusions. Mayo Clin Proc. 2016;91(6):812-9. https://doi.org/10.1016/j.ma yocp.2016.03.001.

16. Stuart T, Butler A, Hoffman P, Hafemeister C, Papalexi E, Mauck WM III, et al. Comprehensive integration of single-cell data. Cell. 2019;177(7):1888-902. https://doi.org/10.1016/j.cell.2019.05.031.

17. Bronte $V$, Ugel $S$, Tinazzi $E$, Vella $A$, de Sanctis $F$, Canè $S$, et al. Baricitinib restrains the immune dysregulation in patients with severe COVID-19. J Clin Invest. 2020;130(12):6409-16. https://doi.org/10.1172/JCl141772.

18. Solito S, Pinton L, de Sanctis F, Ugel S, Bronte V, Mandruzzato S, et al. Methods to measure MDSC immune suppressive activity in vitro and in vivo. Curr Protoc Immunol. 2019;124(1):e61. https://doi.org/10.1002/ cpim.61.

19. Liao M, Liu Y, Yuan J, Wen Y, Xu G, Zhao J, et al. Single-cell landscape of bronchoalveolar immune cells in patients with COVID-19. Nat Med. 2020; 26(6):842-4. https://doi.org/10.1038/s41591-020-0901-9.

20. Bost $P$, et al. Host-viral infection maps reveal signatures of severe COVID-19 patients. Cell. 2020;181(7):1475-88.e12. https://doi.org/10.1016/ j.cell.2020.05.006

21. Schulte-Schrepping J, et al. Severe COVID-19 is marked by a dysregulated myeloid cell compartment. Cell. 2020;182(6):1419-40.e23. https://doi.org/1 0.1016/j.cell.2020.08.001.

22. Turner MD, Nedjai B, Hurst T, Pennington DJ. Cytokines and chemokines: at the crossroads of cell signalling and inflammatory disease. Biochim Biophys Acta. 2014;1843(11):2563-82. https://doi.org/10.1016/j.bbamcr.2014.05.014.

23. Galleu A, et al. Apoptosis in mesenchymal stromal cells induces in vivo recipient-mediated immunomodulation. Sci Transl Med. 2017;9(416): eaam7828. https://doi.org/10.1126/scitranslmed.aam7828.

24. Fajgenbaum DC, June CH. Cytokine storm. N Engl J Med. 2020;383(23): 2255-73. https://doi.org/10.1056/NEJMra2026131.

25. Blazar BR, MacDonald KPA, Hill GR. Immune regulatory cell infusion for graftversus-host disease prevention and therapy. Blood. 2018;131(24):2651-60. https://doi.org/10.1182/blood-2017-11-785865

26. Leibacher J, Henschler R. Biodistribution, migration and homing of systemically applied mesenchymal stem/stromal cells. Stem Cell Res Ther. 2016;7(1):7. https://doi.org/10.1186/s13287-015-0271-2.

27. Armitage J, Tan DBA, Troedson R, Young P, Lam KV, Shaw K, et al. Mesenchymal stromal cell infusion modulates systemic immunological responses in stable COPD patients: a phase I pilot study. Eur Respir J. 2018; 51(3):1702369. https://doi.org/10.1183/13993003.02369-2017.

28. Lee RH, Pulin AA, Seo MJ, Kota DJ, Ylostalo J, Larson BL, et al. Intravenous hMSCs improve myocardial infarction in mice because cells embolized in lung are activated to secrete the anti-inflammatory protein TSG-6. Cell Stem Cell. 2009;5(1):54-63. https://doi.org/10.1016/j.stem.2009.05.003.

29. Krasnodembskaya A, Song Y, Fang X, Gupta N, Serikov V, Lee JW, et al. Antibacterial effect of human mesenchymal stem cells is mediated in part from secretion of the antimicrobial peptide LL-37. Stem Cells. 2010;28(12): 2229-38. https://doi.org/10.1002/stem.544

30. Hu S, Park J, Liu A, Lee JH, Zhang X, Hao Q, et al. Mesenchymal stem cell microvesicles restore protein permeability across primary cultures of injured human lung microvascular endothelial cells. Stem Cells Transl Med. 2018; 7(8):615-24. https://doi.org/10.1002/sctm.17-0278.

31. Court AC, et al. Mitochondrial transfer from MSCs to T cells induces Treg differentiation and restricts inflammatory response. EMBO Rep. 2020;21(2): e48052. https://doi.org/10.15252/embr.201948052.

32. Islam MN, Das SR, Emin MT, Wei M, Sun L, Westphalen $K$, et al. Mitochondrial transfer from bone-marrow-derived stromal cells to pulmonary alveoli protects against acute lung injury. Nat Med. 2012;18(5): 759-65. https://doi.org/10.1038/nm.2736.

33. Khoury M, Cuenca J, Cruz FF, Figueroa FE, Rocco PRM, Weiss DJ. Current status of cell-based therapies for respiratory virus infections: applicability to COVID-19. Eur Respir J. 2020;55(6):2000858. https://doi.org/10.1183/13993 003.00858-2020

34. Gupta N, Su X, Popov B, Lee JW, Serikov V, Matthay MA. Intrapulmonary delivery of bone marrow-derived mesenchymal stem cells improves survival and attenuates endotoxin-induced acute lung injury in mice. J Immunol. 2007;179(3):1855-63. https://doi.org/10.4049/jimmunol.179.3.1855.

35. Lee JW, Fang X, Gupta N, Serikov V, Matthay MA. Allogeneic human mesenchymal stem cells for treatment of $E$. coli endotoxin-induced acute lung injury in the ex vivo perfused human lung. Proc Natl Acad Sci U S A. 2009;106(38):16357-62. https://doi.org/10.1073/pnas.0907996106.

36. Yang Y, Hu S, Xu X, Li J, Liu A, Han J, et al. The vascular endothelial growth factors-expressing character of mesenchymal stem cells plays a positive role in treatment of acute lung injury in vivo. Mediators Inflamm. 2016;2016: 2347938-12. https://doi.org/10.1155/2016/2347938.

37. Hu S, Li J, Xu X, Liu A, He H, Xu J, et al. The hepatocyte growth factorexpressing character is required for mesenchymal stem cells to protect the lung injured by lipopolysaccharide in vivo. Stem Cell Res Ther. 2016;7(1):66. https://doi.org/10.1186/s13287-016-0320-5.

38. Ziegler-Heitbrock $L$, Hofer TPJ. Toward a refined definition of monocyte subsets. Front Immunol. 2013:4:23. https://doi.org/10.3389/fimmu.2013. 00023. 
39. Randolph GJ, Sanchez-Schmitz G, Liebman RM, Schakel K. The CD16(+) (Fcgam- maRIII(+)) subset of human monocytes preferentially becomes migratory dendritic cells in a model tissue setting. J Exp Med. 2002;196(4): 517-27. https://doi.org/10.1084/jem.20011608

40. Bajana S, et al. Differential CD4(+) T-cell memory responses induced by two subsets of human monocyte-derived dendritic cells. Immunology. 2007: 122(3):381-93. https://doi.org/10.1111/j.1365-2567.2007.02650.x.

41. Allen A, Vaninov N, Li M, Nguyen S, Singh M, Igo P, et al. Mesenchymal stromal cell bioreactor for ex vivo reprogramming of human immune cells. Sci Rep. 2020;10(1):10142. https://doi.org/10.1038/s41598-020-67039-w.

42. Trovato R, et al. Immunosuppression by monocytic myeloid-derived suppressor cells in patients with pancreatic ductal carcinoma is orchestrated by STAT3. J Immunother Cancer. 2019;7(1):255. https://doi.org/10.1186/s4042 5-019-0734-6.

\section{Publisher's Note}

Springer Nature remains neutral with regard to jurisdictional claims in published maps and institutional affiliations.

Ready to submit your research? Choose BMC and benefit from:

- fast, convenient online submission

- thorough peer review by experienced researchers in your field

- rapid publication on acceptance

- support for research data, including large and complex data types

- gold Open Access which fosters wider collaboration and increased citations

- maximum visibility for your research: over $100 \mathrm{M}$ website views per year

At BMC, research is always in progress.

Learn more biomedcentral.com/submissions 